\title{
Kesadaran Hukum Masyarakat Pemalang Terhadap Pilkada Serentak Tahun 2020 di Era Pandemi Covid-19
}

\author{
Imaro Sidqi ${ }^{1}$ \\ ${ }^{1}$ Fakultas Syari'ah, IAIN Pekalongan. E-mail: imarosidqi@gmail.com
}

\begin{tabular}{|c|c|}
\hline Article & Abstract \\
\hline $\begin{array}{l}\text { How to cite: } \\
\text { Imaro Sidqi, 'Kesadaran } \\
\text { Hukum Masyarakat } \\
\text { Pemalang Terhadap } \\
\text { Pilkada Serentak Tahun } \\
2020 \text { di Era Pandemi } \\
\text { Covid-19' (2020) Vol. } 1 \\
\text { No. } 2 \text { Rechtenstudent } \\
\text { Journal Fakultas Syariah } \\
\text { IAIN Jember. } \\
\text { Histori artikel: } \\
\text { Submit } 8 \text { April 2020; } \\
\text { Diterima } 11 \text { Juli 2020; } \\
\text { Diterbitkan } 5 \text { Agustus } \\
\text { 2020. } \\
\text { ISSN: } \\
\text { 2723-0406 (media cetak) }\end{array}$ & $\begin{array}{l}\text { This paper aims to seek or develop public legal awareness and efforts to develop the } \\
\text { Pilkada in the Covid-19 Pandemi Era. The research method used in this paper uses } \\
\text { juridical empirical, with a qualitative approach. The data technique uses observation, } \\
\text { interviews, and literature studies. Data checking techniques used triangulation and } \\
\text { analysis using interactive models. The results showed that the awareness of } \\
\text { Pemalang Regency people in the middle to lower category was still low, while } \\
\text { people with the middle to upper category had started to have knowledge and } \\
\text { understanding of the simultaneous regional elections and their policies and how the } \\
\text { procedures were in the era of the Covid-19 pandemi. In addition, the attitudes and } \\
\text { behavior of the middle to upper class society have begun to be structured, } \\
\text { considerations for choosing, exercising their rights and obligations, and } \\
\text { reprimanding officers who underestimate their duties. The factors that influence the } \\
\text { legal awareness of Pemalang Regency society, namely: education, economy, religion, } \\
\text { and socio-cultural factors. Then, efforts to build their awareness through counseling } \\
\text { and campaigns about simultaneous regional elections, especially during the Covid- } \\
\text { 19 pandemic. } \\
\text { Keywords: Simultaneous Regional Elections, Legal Awareness, Voting Society, and Covid- } \\
19 \\
\text { Abstrak }\end{array}$ \\
\hline
\end{tabular}




\section{Pendahuluan}

Hadirnya Covid-191 membawa perubahan yang sangat besar²; perubahan dalam sektor ekonomi, sosial, maupun sektor-sektor yang lainnya. Tentunya atas perubahan tersebut berdampak terhadap masyarakat secara luas dari segala sisi kehidupannya, sehingga menjadi kewajiban bagi para pemimpin di suatu wilayah tertentu untuk berjuang dalam menangani permasalahan-permasalahan tersebut. ${ }^{3}$ Saat ini kepemimpinan mereka sedang diuji, bagaimana memberikan pelayanan yang terbaik bagi rakyat secara keseluruhan, untuk itu dibutuhkan perwujudan pemimpin yang mempunyai jiwa yang peduli dengan masyarakat dan tidak memimpin suatu Negara maupun wilayah hanya untuk kepentingan pribadi semata. Untuk mencari sosok pemimpin yang baik dan benar, maka dibutuhkan perekrutan yang baik pula; dari Paslon (pasangan calon), partai politik, pemilih, serta penyelenggaraannya. ${ }^{4}$ Semua itu menjadi sebuah sistem yang tidak dapat dipisahkan untuk menciptakan sosok seorang pemimpin yang diidamkan oleh masyarakatnya.

Dalam konteks ke-Indonesiaan, seorang pemimpin dilahirkan melalui pesta demokrasi yang seringkali disebut Pemilu dan Pilkada. Pemilu dan Pilkada merupakan kegiatan memilih dan dipilih pasangan/ kandidat calon pasangan yang akan menjadi seorang pemimpin dan dilakukan melalui pemungutan suara dengan hasil yang paling terbanyak. ${ }^{5}$ Sebagaimana yang diamanatkan dalam Konstitusi, ${ }^{6}$ bahwa hadirnya pemilu maupun Pilkada bertujuan agar doa rakyat (kedaulatan rakyat) dapat tersemogakan/tersampaikan di saat pemimpin tersebut menempatkan posisinya di kursi yang telah disediakan. ${ }^{7}$ Jadi, konsekuensi logisnya bahwa bakal calon pemimpin yang nantinya terpilih memang betul-betul pilihan rakyat, amanat rakyat, dan harapan rakyat.

Salah satu pemilihan yang penting bagi mereka adalah Pilkada, Pilkada suatu perwujudan kedaulatan rakyat untuk ikut berpartisipasi dalam dan turut ikut campur pengambilan kebijakan di suatu daerah tertentu, rakyat memilih siapa saja pemimpin yang berhak duduk di atas kursi sebagai perwakilannya agar hak-haknya dapat terealisasikan dengan baik dan benar. ${ }^{8}$ Dengan demikian, hadirnya pemimpin daerah tersebut agar tujuan otonomi daerah sebagaimana amanat konstitusi ${ }^{9}$ tetap terlaksana dengan baik. Maka dari itu, Pilkada tahun ini menjadi hal yang penting bagi masyarakat secara luas untuk kepentingan

\footnotetext{
${ }^{1}$ Corona virus merupakan penyakit yang dapa menyebabkan gejala-gejala seperti penyakit pada umumnya, dimulai dari yang ringan-berat. Penyakit yang sejenis adalah SARS dan MERS. Penyebaran virus corona antar manusia atau antar makhluk hidup yang lain sangat mudah sekali, sehingga perlu kehati-hatian. Kementerian Kesehatan RI, Pedoman Pencegahan dan Pengendalian Coronavirus Disease (Coid-19), (Jakarta: Kemenkes RI, 2020$), 11$.

${ }^{2}$ Chairul Ikhsan Burhanuddin, Ancaman Krisis Ekonomi Global Dari Dampak Penyebaran Virus Corona (Jurnal Akmen, Volume 17 Nomor 1 Maret 2020), 90-92.

${ }^{3}$ Gemma D’Auria dan Aaron de Smet, Kepemimpinan di Masa Krisis: Menghadapi Wabah Virus Corona dan Tantangan di Masa Depan (Mc Kinsey \& Company, Maret 2020), 1-2.

${ }^{4}$ Ainun Najib, "Konstruksi Pemimpin Ideal Untuk Indonesia, Jurnal Agama dan Hak Asasi Manusia" (Vol. 3, No. 1, Tahun 2013), 145-153.

${ }^{5}$ Sri Nuryanti, “Intervensi Penyelenggaraan Pemilukada: Regulasi, Sumberdaya, dan Eksekusi” (Jurnal Ilmu sosial dan ilmu politik, Vol. 19, Nomor 2, Tahun 2015), 126-129.

${ }^{6}$ Pasal 1 ayat 2 dan Pasal 22E Undang-Undang Dasar Negara Republik Indonesia Tahun 1945

7 Susilo, "Mahar Politik Sebagai Bagian Dari Unsur Tindak Pidana", dalam (Jurnal Seminar Nasional Hukum Universitas Negeri Semarang Volume 4 Nomor 2 Tahun 2018), 155.

8 Yusdianto, "Identifikasi Potensi Pelanggaran Pemilihan Kepada Daerah (Pilkada) dan Mekanisme Penyelesaiannya" (Jurnal Konstitusi, Vol II No.2, November 2020), 44.

${ }_{9}$ Pasal 18 Undang-Undang Dasar Negara Republik Indonesia Tahun 1945
} 
wilayahnya masing-masing. Agar Pilkada pada tahun ini berjalan dengan lancar, maka perlu adanya upaya evaluasi pada Pilkada serentak yang dijalankan di tahun sebelumnya.

Pilkada serentak di tahun-tahun sebelumnya masih mengalami problematika, beberapa di antaranya: 1) tidak akuratnya data pemilih tetap (DPT), 2) netralitas dari penyelenggara yang masih terdapat masalah, 3) masih banyaknya money politic. Semua itu akan berdampak bagi pemilih, partai politik, penyelenggara, hingga pemerintah dikarenakan akan membutuhkan modal dan usaha yang lebih besar daripada Pilkada yang sebelumnya, sehingga pemerintah beserta para penyelenggara harus mengonsepsikan strategi yang baru agar Pilkada tetap terlaksana, namun hasilnya pun juga tetap maksimal.

Pilkada serentak pada tahun 2020 ini harus diupayakan agar terlaksana dengan optimal oleh KPU dan KPUD dengan berpedoman atas evaluasi Pilkada pada tahun sebelumnya, estimasi waktunya bahwa pemilihan kepala daerah (Pilkada) akan dilaksanakan pada tanggal 23 September 2020 yang akan dilaksanakan di 270 daerah (9 Provinsi, 224 Kabupaten, dan 37 Kota $)^{10}$, namun terdapat 2 daerah yang tidak serentak yakni Provinsi Aceh dan Provinsi DKI Jakarta karena memiliki kekhususan yang menjadikan 2 daerah tersebut harus melaksanakan secara individu.

Pilkada serentak tahun 2020 ini bertabrakan dengan pandemi Covid-19, itu artinya bahwa beban Pilkada tahun ini akan lebih berat dibandingkan dengan tahun-tahun sebelumnya, permasalahan demi permasalahan akan semakin kompleks sehingga diperlukan banyak solusi agar kompleksitas permasalahan tersebut dapat teratasi dengan efektif dan efisien. Maka, agar semuanya berjalan dengan lancar dibutuhkan kerja keras KPU dan KPUD dalam memaksimalkan kerja serta anggaran yang ada. Tidak hanya itu, kesadaran hukum masyarakat juga menjadi hal yang penting untuk saat ini; kesadaran hukum yang selalu beriringan dengan perbuatan masyarakat dalam memilih serta dipilih dalam pesta demokrasi, kesadaran hukum ini tentunya akan mempengaruhi hasil pemilihan yang baik maupun hasil yang buruk. Oleh karena itu, kesadaran hukum masyarakat terhadap pemilihan juga menjadi hal yang penting dan utama untuk mewujudkan tujuan hukum. Hal ini tentunya sesuai dengan pernyataan Soerjono Soekanto yang menjelaskan bahwa kesadaran hukum masyarakat merupakan faktor penting dalam mewujudkan tujuan hukum. ${ }^{11}$ Artinya, kesadaran hukum mempengaruhi bekerjanya hukum dalam suatu masyarakat.

Penelitian yang dilakukan oleh Bawaslu Republik Indonesia menyatakan bahwa banyaknya pelanggaran pemilihan disebabkan karena kesadaran hukum masyarakat yang masih terbilang rendah; masyarakat tidak tahu dan paham terhadap politik atau prosedur pemilihan yang kurang logis bagi mereka. Alasan ini berdampak terhadap hasil pemilihan yang tidak sesuai dengan yang diharapkan. ${ }^{12}$

Hal tersebut semakin menarik dan relevan untuk dibahas lebih lanjut dalam konteks lokal Kabupaten Pemalang yang masih cukup primitif dan individualistik dalam hal pemilihan terutama Pilkada yang nantinya akan menjadi bagian penting dan utama di kabupaten tersebut. Jumlah penduduk Kabupaten Pemalang sebanyak 1.305.668 jiwa dengan

\footnotetext{
10 Septianto, Daftar 270 daerah penyelenggara Pilkada serentak pada 2020, https://tirto.id/daftar-270-daerahpenyelenggara-Pilkada-serentak-pada-2020-ecZT, di kunjungi pada tanggal 22 Juli 2020.

${ }^{11}$ Soerjono Soekanto, Kesadaran Hukum Dan Kepatuhan Hukum, (Edisi Pert. Jakarta: CV. Rajawali, 1982$), 180$.

12 Fitria Farisa, https://nasional.kompas.com/read/2018/10/26/18442551/bawaslu-klaim-banyaknya-pelanggaranpemilu-karena-rendahnya-kesadaran-hukum, di kunjungi pada tanggal 17 Agustus 2020.
} 
persentase umur 17 tahun ke atas adalah 80 persen. ${ }^{13}$ Data tersebut membuktikan bahwa peserta pemilih di Kabupaten ini sangat banyak. Banyaknya pemilih tersebut masih belum semuanya paham terhadap kontestasi Pilkada, masyarakat memahami pemilihan sebagai sub sistem yang dikemas oleh para elit politik saja, sehingga membuat masyarakat malas untuk berpartisipasi dalam pemilihan Pilkada dikarenakan anggapan mereka bahwa pemimpin yang menduduki kursi jabatannya sangat mudah untuk ditebak di Kabupaten itu, ditambah hadirnya Covid-19 ini yang memaksa masyarakat untuk selalu menggunakan protokol kesehatan sesuai dengan aturan yang berlaku saat ini. ${ }^{14}$

Maka dari itu, peneliti menganggap bahwa hal tersebut menarik untuk dibahas dalam kacamata kesadaran hukum Masyarakat Pemalang terhadap pemilihan Pilkada di Era Pandemi Covid-19 ini, dirumuskan dengan 4 indikator; pengetahuan, pemahaman, sikap, dan perilaku yang menjadi dasar kehidupan mereka. Tujuannya agar diketahui seberapa jauh pemahaman serta tindakan yang dilakukan oleh masyarakat Kabupaten Pemalang akan Pilkada serentak tahun 2020 ini, sehingga dapat diberikan solusi oleh peneliti serta rekomendasi agar Pilkada di tahun ini sesuai dengan tujuan hukum sebagaimana di amanatkan dalam konstitusi. Peneliti berargumen bahwa kesadaran hukum masyarakat Kabupaten Pemalang terhadap partisipasi pemilihan di Era Covid-19 dipengaruhi oleh faktor pendidikan, ekonomi, agama, dan lingkungan sosial budaya.

\section{Rumusan Masalah}

Adapun permasalahan yang diangkat menjadi pokok masalah sebagai berikut :

1. Bagaimana Masyarakat di Kabupaten Pemalang di Era Pandemi Covid-19?

2. Bagaimana Kesadaran Hukum Masyarakat Pemalang Terhadap Pilkada di Era Pandemi Covid-19?

3. Bagaimana Membangun Kesadaran Hukum Masyarakat Terhadap Pilkada di Era Pandemi Covid-19?

\section{Metode Penelitian}

Penelitian yuridis empiris ini menggunakan pendekatan kualitatif yang mengkaji tentang perilaku masyarakat yang timbul akibat berinteraksi dengan sistem norma yang berlaku dalam realitas masyarakat ${ }^{15}$. Lokasi penelitian di Kabupaten Pemalang dengan $80 \%$ penduduk berumur 17 tahun ke atas. Data primer diperoleh dengan teknik observasi dan wawancara. Data sekunder diperoleh dengan menggunakan studi literer, yaitu menelusuri bahan hukum primer dan bahan hukum sekunder. Pengecekan kredibilitas data menggunakan triangulasi. Teknik analisis menggunakan Interactive Model, yang meliputi kegiatan, antara lain: mengumpulkan data, menyajikan data; reduksi data dan penarikan simpulan. Siklus ini dilakukan dengan siklus yang tidak terputus. ${ }^{16}$

\footnotetext{
13 BPS Kab. Pemalang, https://pemalangkab.bps.go.id/statictable/2015/03/19/51/proyeksi-penduduk-kabupatenpemalang-menurut-kecamatan-dan-jenis-kelamin-2010-2020.html, di kunjungi pada tanggal 17 Agustus 2020.

14 Keputusan Menteri Kesehatan Republik Indonesia Nomor. HK.01.07/Menkes/382/2020 tentang Protokol Kesehatan Bagi Masyarakat.

${ }^{15}$ Setandjo Wignjosoebroto, Hukum, Paradigma, Metode Dan Dinamika Masalahnya (Jakarta: Penerbit HuMA, 2002), 143.

${ }^{16}$ Matthew B Milles., and A. Michael Huberman, "An Expanded Soucers Book: Qualitative Data Analyses", (Sage Publications, 1992), 250.
} 


\section{Hasil dan Pembahasan}

\section{Konsep Kesadaran Hukum}

Kesadaran hukum pada hakikatnya merupakan kesadaran manusia tentang suatu nilainilai yang ada di dalam diri manusia tersebut tentang hukum yang ada; baik hukum yang bersifat ius constitutum ataupun hukum yang bersifat ius constituendum. ${ }^{17}$ Menurut Sudikno Mertokusumo menjelaskan kembali dengan tegas bahwa kesadaran hukum merupakan apa yang seharusnya/ seyogyanya kita perbuat atau lakukan terhadap yang sepantasnya, dengan tidak melakukan hal-hal di luar batas dengan orang lain. ${ }^{18}$ Paul Scholten juga mendefinisikan tentang kesadaran hukum yang diartikan sebagai kesadaran yang berada dalam diri manusia tentang seputar hukum yang mereka perbuat di suatu wilayah tertentu; tentang seyogyanya yang kita lakukan dan seyogyanya yang tidak kita lakukan. ${ }^{19}$

Dari pemaparan tersebut, secara sederhana dapat dipahami bahwa kesadaran hukum menjadi sebuah mediator antara perilaku masyarakat baik secara individu ataupun kolektif dengan hukum itu sendiri. Secara substansi kesadaran hukum menjadi hal yang kognitif yang dapat mempengaruhi hubungan antar hukum dengan kebiasaan hidup masyarakat, dapat diartikan bahwa apabila seseorang memiliki kesadaran hukum yang tinggi, maka dapat membedakan perbuatan yang benar atau perbuatan yang tidak benar sesuai dengan hukum. Secara garis besar bahwa indikator kesadaran hukum ada 4, yakni; pengetahuan hukum, pemahaman hukum, sikap hukum, perilaku hukum. Dari setiap indikator memiliki tingkatan kesadaran hukum di mulai dari yang terendah hingga yang tertinggi. ${ }^{20}$

Pengetahuan sendiri berasal dari kata "tahu" yang diartikan bahwa seseorang tahu terhadap objek tertentu melalui pengindraannya; baik indera penglihatan, pendengaran, penciuman, rasa, dan raba. Pengetahuan manusia sebagai besar cenderung didapatkan dari indra mata dan telinga. ${ }^{21}$ Sedangkan pengetahuan hukum merupakan pengetahuan dari seseorang terhadap perbuatan/ perilaku yang telah diatur oleh hukum, baik hukum yang bersifat tertulis maupun hukum yang bersifat tidak tertulis. Secara dasarnya bahwa pengetahuan tersebut sangat berkaitan dengan perilaku yang diperbolehkan ataupun perilaku yang tidak diperbolehkan oleh hukum yang telah mengaturnya. Pengetahuan hukum secara umum diasumsikan pengetahuan yang erat dengan asumsi masyarakat terhadap hukum yang bersifat tertulis (diundangkan). ${ }^{22}$ Menurut Kutschinsky ada 2 klasifikasi dari pengetahuan hukum, yakni; pengetahuan terhadap hukum positif (hukum yang berlaku saat ini) dan pengetahuan terhadap substansi hukum (isi hukum). Pengetahuan terhadap hukum yang berlaku adalah pengetahuan seseorang terhadap hukum yang telah diatur, secara khususnya yang berkaitan dengan perilaku masyarakat yang diperbolehkan ataupun tidak diperbolehkan. Masyarakat dianggap mengetahui isi suatu peraturan manakala peraturan tersebut telah di undangkan. Artinya, pengetahuan hukum adalah pengertian terhadap isi dan tujuan dari suatu peraturan hukum tertulis dan manfaatnya bagi para pihak. ${ }^{23}$

Kemudian, pemahaman berawal dari kata "paham' yang bermakna suatu kemampuan seseorang untuk menjelaskan secara jelas tentang suatu objek yang telah diketahui

\footnotetext{
${ }^{17}$ Soerjono Soekanto, “Kesadaran Hukum Dan Kepatuhan Hukum”, (Edisi Pert. Jakarta: CV. Rajawali, 1982$), 181$.

18 Soerjono Soekanto, 182.

19 Soerjono Soekanto, 182.

20 Soerjono Soekanto, 215.

${ }^{21}$ Sukidjo Notoatmodjo, Metodologi Riset Kesehatan, (Jakarta: Rineka Cipta, 2010), 78.

22 Soerjono Soekanto, 215.

23 Soerjono Soekanto, 215.
} 
sebelumnya, serta dapat mendefinisikan maupun menginterpretasikan objek tersebut dengan benar. Pemahaman hukum bisa saja diartikan seseorang yang telah mengetahui seputar informasi tertentu terhadap isi peraturannya, sehingga dapat diartikan bahwa pengetahuan hukum merupakan suatu pengertian dari isi aturan dalam hal tujuan, manfaat yang terkandung di dalamnya baik hukum yang bersifat tertulis maupun hukum yang bersifat tidak tertulis. ${ }^{24}$

Sikap hukum merupakan suatu kecenderungan seseorang yang sudah menempatkan posisinya untuk memilih hukum itu sendiri baik diterima dan ditolak, sehingga memunculkan apresiasi terhadap hukum. Hukum sudah dinilai baik dan buruknya oleh seseorang tersebut tergantung dari aspek pengetahuan serta pemahaman yang ada sebelumnya, kemudian perilaku hukum diartikan aturan yang berlaku yang kemudian di taati atau tidak ditaati oleh masyarakatnya itu sendiri, dari sikap yang sudah dimilikinya selanjutnya memunculkan kebiasaan atas cerminan dari kondisi yang sebelumnya. ${ }^{25}$

Jadi, dari beberapa indikator di atas mengartikan bahwa kesadaran hukum dapat di ukur secara konsepnya. Tinggi ataupun rendahnya suatu kesadaran masyarakat tidak terlepas dari ukuran-ukuran tersebut, jika indikator di atas sudah terpenuhi, maka bisa jadi masyarakat memiliki tingkat kesadaran hukum yang tinggi dan sebaliknya, jika indikator tersebut tidak terpenuhi, maka kesadaran hukum masyarakat di suatu wilayah tertentu terbilang masih rendah.

\section{Masyarakat di Kabupaten Pemalang di Era Pandemi Covid-19}

Kabupaten Pemalang merupakan kabupaten di provinsi Jawa Tengah, ibu kotanya adalah Kota Pemalang yang mayoritas penduduknya adalah Islam. Alih-alih nuansa keberagaman mewarnai setiap sendi kehidupan masyarakatnya, baik dalam bidang ekonomi, sosial maupun pilihan politiknya. Jumlah penduduk Kabupaten Pemalang sebanyak 1.305.668 jiwa dengan persentase umur 17 tahun ke atas adalah 80 persen. Dari data tersebut mengartikan bahwa sebanyak 1.044.534 jiwa berhak menjadi DPT (Daftar Peserta Pemilih) dalam pemilihan kepala daerah (Pilkada) tahun 2020 ini. ${ }^{26}$ Sebagaimana yang telah diatur dalam Pasal 68 Undang-Undang No 32 Tahun 2004 Tentang Pemerintahan Daerah yakni "pada hari pemungutan suara pemilihan kepala daerah dan wakil kepala daerah sudah berumur 17 (tujuh belas) tahun atau sudah/pernah kawin mempunyai hak memilih". ${ }^{27}$

Berbicara tentang Kabupaten tersebut secara sosial-ekonomi, tingkat laju ekonomi yang ada di Pemalang masih terbilang rendah bahkan selalu turun dari tahun ke tahun, namun pada tahun 2015-2019 terakhir ini mulai ada peningkatan pertumbuhan ekonomi yang cukup pesat ${ }^{28}$, cukup pesatnya pertumbuhan tersebut tidak semerta-merta menjadikan Kabupaten Pemalang memiliki ekonomi yang tinggi, akan tetapi tetap saja masih terbilang rendah dalam pencapaian ekonomi masyarakatnya. ${ }^{29}$ Tentunya dari hal tersebut menjadikan masyarakat mencari-cari apapun itu yang dapat melengkapi kebutuhan hidupnya baik bekerja buruh,

\footnotetext{
${ }^{24}$ Triana Sofiani, "Kesadaran Hukum Konsumen Muslim di Pekalongan Terhadap Produk Berlabel Halal di Era Masyarakat Ekonomi ASEAN" (al-ahkam Jurnal Ilmu Syariah dan Hukum, Vol. 2, Nomor 2, 2017), 1

${ }^{25}$ Soerjono Soekanto, 215.

26 BPS Kab. Pemalang, https://pemalangkab.bps.go.id/statictable/2015/03/19/51/proyeksi-penduduk-kabupatenpemalang-menurut-kecamatan-dan-jenis-kelamin-2010-2020.html, di akses pada 17 Agustus 2020.

${ }_{27}$ Pasal 68 Undang-Undang No 32 Tahun 2004 tentang Pemerintahan Daerah.

${ }^{28}$ Pemalang dalam angka, 2020.

${ }^{29}$ Pemalang dalam angka, 2020.
} 
berdagang, kuli, dan lain sebagainya. ${ }^{30}$ Di tambah hadirnya Covid-19; Pemalang salah satu kabupaten yang menjadi perhatian khusus/ zona merah dikarenakan bertambahnya kasus Covid-19 yang selalu meningkat ${ }^{31}$, bertambahnya kasus secara terus menerus menjadikan pertumbuhan ekonomi semakin menurun; terdapat beberapa masyarakat yang tidak bekerja/ diPHK atas dampak Covid-19 tersebut menjadikan laju pertumbuhan ekonomis menurun drastis. ${ }^{32}$

Selain itu, tingkat pendidikan di Kabupaten Pemalang juga masih terbilang minim, sedikit sekali masyarakatnya yang berpendidikan perguruan tinggi. Parahnya hadirnya Covid-19 juga mempengaruhi kualitas pendidikannya, berdasarkan hasil survei yang diteliti oleh BPS Kabupaten Pemalang 82,25 \% minimnya kuota internet atas dampak sekolah online serta 92\% menyatakan bahwa sekolah online sangatlah tidak efektif dan efisien. Dari data tersebut menunjukkan bahwa tingkat pendidikan di Kabupaten Pemalang mulai terkikis dengan hadirnya pandemi Covid-19.

Berdasarkan kondisi tersebut maka, pemilihan kepala daerah (Pilkada) pada tahun ini memiliki kompleksitas permasalahan yang beragam; tentunya akan berpengaruh terhadap proses serta hasil dari pemilihan itu sendiri. Untuk dilanjutkan sebagai bahan penelitian terhadap kesadaran masyarakat Kabupaten Pemalang terhadap Pilkada serentak di era pandemi Covid-19, penulis membagi menjadi 2 kategori, yakni; kategori masyarakat menengah ke bawah dan kategori menengah ke atas. Kategori menengah ke bawah adalah masyarakat yang secara ekonomi rendah, pendidikan rendah, pengalaman minim dan hidup serta bergaul di lingkungan masyarakat yang secara sosial ekonomi lemah. Sedangkan masyarakat menengah ke atas adalah masyarakat yang secara sosial ekonomi berada pada tingkat menengah ke atas, yaitu memiliki tingkat pendidikan, ekonomi, pengalaman dan hidup serta bergaul di lingkungan menengah ke atas.

\section{Kesadaran Hukum Masyarakat Pemalang Terhadap Pilkada di Era Pandemi Covid- 19}

Pengetahuan hukum masyarakat terhadap pesta demokrasi Pilkada (pemilihan kepala daerah) dipengaruhi oleh beberapa faktor; faktor pendidikan, ekonomi, pengalaman, informasi dan lingkungan di mana mereka bergaul. Masyarakat dalam hal ini menjadi 2 kategori, yakni; kategori masyarakat menengah ke bawah dan kategori menengah ke atas. Kategori menengah ke bawah adalah masyarakat yang secara ekonomi rendah, pendidikan rendah, pengalaman minim dan hidup serta bergaul di lingkungan masyarakat yang secara sosial ekonomi lemah. Sedangkan masyarakat menengah ke atas adalah masyarakat yang secara sosial ekonomi berada pada tingkat menengah ke atas, yaitu memiliki tingkat pendidikan, ekonomi, pengalaman dan hidup serta bergaul di lingkungan menengah ke atas.

Fakta tersebut membuktikan bahwa pengetahuan antara masyarakat menengah ke atas dan masyarakat menengah ke bawah memiliki perbedaan yang cukup signifikan. Pada masyarakat menengah ke bawah tidak memiliki pengetahuan yang mendalam terhadap kontestasi pemilihan khususnya pengetahuan tentang Pilkada (pemilihan kepala daerah) serentak, pengetahuan mereka terhadap Pilkada terbatas pada pemilihan yang seperti pada

\footnotetext{
${ }^{30}$ Pemalang dalam angka, 2020

${ }^{31}$ Infocorona.pemalangkab.go.id.

32 BPS Kabupaten Pemalang, Profil Masyarakat Kabupaten Pemalng di Era New Normal (Analisis Hasil Survey Sosial Ekonomi Dampak Covid-19) (Pemalang: BPS Kab. Pemalang, 2020), 27-32.
} 
umumnya (pemilu) dan terbatas pengetahuannya terhadap lembaga-lembaga yang berkontribusi dalam Pilkada sebagaimana KPU, KPUD, ataupun Bawaslu. Selain itu, pada masyarakat menengah ke bawah juga tidak tahu seperti apakah bentuk-bentuk pelanggaran pada Pilkada beserta cara pelaporannya, mereka hanya memahami bahwa bentuk pelanggaran Pilkada pada tingkatan money politic saja. Padahal masih banyak bentuk-bentuk pelanggaran yang merugikan masyarakat sendiri seperti kampanye hitam, memberikan hadiah kepada pihak-pihak tertentu, pemalsuan identitas, dan lain sebagainya. Di tambah di Era Covid-19 yang serba online akan lebih banyak lagi pelanggaran-pelanggaran yang kompleks, maka dari itu Bawaslu menghadirkan Gakkumdu (sentra penegakan hukum terpadu) berbasis online untuk mempermudah masyarakat melaporkan kasus-kasus secara via online, kemudian Gerakan klik serentak yang di hadirkan oleh KPU untuk mempermudah masyarakat berpartisipasi secara online dalam kontestasi pemilihannya, dan lain sebagainya. ${ }^{33}$

Fakta tersebut terlihat dari hasil wawancara dengan beberapa masyarakat dimulai dari pemula (umur 17-21 tahun) dan masyarakat yang berumur 21+. Pengetahuan masyarakat terhadap Pilkada hanya sekedar pemilihan yang diusung dalam jangka waktu 5 tahun sekali sebagaimana pemilihan pada umumnya (pemilu/pilkades), tanpa mengetahui perbedaannya dengan Pilkada, aturannya bagaimana, siapa-siapa saja yang diperbolehkan menjadi peserta dan kandidat, serta pelanggaran-pelanggaran apa saja yang tidak diperbolehkan dilakukan oleh peserta maupun kandidat. Pengetahuan mereka tidak sampai ke tahap isi daripada aturan perundang-undangan. Lebih parahnya mereka beranggapan bahwa pemimpin yang jadi nantinya bukan karena kualitas dirinya, akan tetapi karena harta kekayaannya. Selain itu pula, pada masyarakat menengah ke bawah masih tidak taat terhadap aturan penggunaan protokol kesehatan, masker hanya dipakai ketika masih ada aparat beroperasi, namun setelahnya itu dilepas kembali, mereka belum mengetahui betapa pentingnya aturan-aturan yang sudah diatur dengan begitu mendalam oleh lembaga yang berwenang.

Alasan masyarakat menengah ke bawah tidak mengetahui peraturan-peraturan tersebut dikarenakan tidak bersekolah dan menganggap bahwa peraturan hanya sebatas urusan negara tanpa melibatkan masyarakat. Padahal tujuan datang atau hadirnya peraturanperaturan tersebut agar Pilkada dapat terlaksana sesuai dengan tujuan utama, itu artinya negara ini telah memperhatikan perintah konstitusi agar kedaulatan rakyat dapat dijalankan sebagaimana mestinya. Kondisi tersebut terjadi karena masyarakat menengah ke bawah tidak pernah mendapatkan informasi mengenai berbagai aturan terkait Pilkada serta aturan pengawasannya.

Pengetahuan masyarakat menengah ke atas terhadap Pilkada lebih mendalam dibandingkan dengan pengetahuan masyarakat menengah ke bawah. Sebagaimana contohnya pengetahuan terhadap lembaga-lembaga yang menangani Pilkada (KPU dan KPUD), masyarakat ada yang mengetahui hanya sekedar nama saja sebagaimana masyarakat menengah ke bawah, namun ada yang mengetahui lebih. Pengetahuan yang lebih ini juga beragam ada yang mengetahui nama lembaga-lembaga beserta tupoksinya dan ada pula yang mengetahuinya sampai ke aturan-aturan yang mengatur tentang Pilkada; baik dari proses persiapan hingga hasilnya. Lebih lanjut pengetahuan mereka terhadap jenis-jenis pelanggaran dalam Pilkada, sebagian besar mereka mengetahui akan hal itu, walau hanya sebatas "mengetahui" saja.

\footnotetext{
${ }^{33}$ Santoso, https://www.google.com/amp/s/amp.suara.com/news/2020/07/15/120857/jelang-Pilkada-2020-kpu-resmiluncurkan-aplikasi-gerakan-klik-serentak, di kunjungi pada tanggal 17 Agustus 2020.
} 
Pemahaman masyarakat terhadap Pilkada juga sangat beragam sebagaimana kategori yang sudah dijelaskan sebelumnya. Pemahaman masyarakat terhadap Pilkada hanya sebatas cover dari pemilihan saja, siapa saja paslon-paslonnya, dan prosedur memilihnya. Mereka juga memahami pelanggaran hanya sebatas pelanggaran money politic, karena pengetahuan mereka tentang Pilkada juga sangat dangkal, bahkan mereka juga tidak mengetahui partaipartai apa saja yang mengusung dari masing-masing kandidat yang dicalonkan. Apalagi memahami kondisi seperti ini yang menjadikan banyak perubahan di setiap sisi peraturannya, mereka sama sekali tidak memahami bagaimana nantinya pada saat persiapan hingga pelaksanaan di saat pandemi Covid-19 seperti ini.

Pemahaman masyarakat menengah ke atas lebih baik dibandingkan dengan kategori masyarakat menengah ke bawah. Pemahaman mereka terhadap Pilkada tidak sebatas nama atau tahu kandidat yang mencalonkan pemimpin daerahnya, namun juga memahami dari proses persiapan, pelaksanaan, hingga hari pemilihannya. Lebih lanjut, mereka memahami tupoksi KPU, KPUD, dan Bawaslu sebagai lembaga pengawas dalam pemilihan, bahkan mereka memahami bagaimana proses pelaporan perkara ketika ada kandidat, peserta pemilih, atau petugas yang melanggar penyelenggaraan pemilihan tersebut baik secara online maupun offline. Dalam kondisi pandemi Covid-19 ini, mereka juga paham bagaimana penyesuaiannya kemudian juga bagaimana aturan protokol kesehatan agar pelaksanaan aman tanpa ada rasa ketakutan.

Dari pemaparan kedua kategori masyarakat tersebut, dapat disimpulkan bahwa pemahaman masyarakat terhadap isi peraturan masih terbilang dangkal, karena mereka tidak mengetahui bagaimana tujuan dan isi daripada peraturan yang telah dibuat serta kebijakankebijakan baru dalam strategi Pilkada dalam kondisi yang baru ini, mereka mengetahui dan memahami peraturan hanya dasar-dasarnya saja.

Terhadap peraturan Pilkada, masyarakat memiliki sikap hukum. Sikap masyarakat menengah ke bawah terhadap aturan yang ada di dalamnya hanya sebatas dalam penerimaan saja. Hal tersebut diartikan bawah masyarakat menengah ke bawah mereka menaati tugastugas yang telah di atur oleh KPU, KPUD, maupun petugas PPBD di desa-desa tentang bagaimana prosedur pemilihannya, siapa saja paslonnya, dan kapan waktu pemilihannya. Begitu juga terhadap peraturan dan pelanggaran-pelanggaran yang ada, mereka masih dalam tahap menerima saja, karena pengetahuan dan pemahaman mereka masih sangat rendah.

Sikap masyarakat menengah ke atas, memiliki perbedaan yang signifikan dengan masyarakat dengan kategori menengah ke bawah. Mereka mempunyai tanggung jawab yang lebih terhadap pesta demokrasi yang memang nantinya juga akan kembali untuk mereka sendiri, tingkat pengetahuan dan pemahaman mereka yang baik sangat berpengaruh terhadap sikap mereka terhadap respons pelaksanaan Pilkada serentak di tahun 2020 ini. Pengetahuan dan pemahaman mereka yang baik mempengaruhi sikap bagi masyarakat yang berkategori menengah ke bawah. Fakta mengenai sikap masyarakat menengah ke bawah, ditunjukkan dari hasil wawancara sebagai berikut; "Saya selalu mencoblos/memilih di setiap pemilihan bupati/ walikota/ gubernur" kata beberapa informan. "Selain mencoblos juga saya melihat bagaimana proses sebelumnya baik dari persiapan hingga pelaksanaannya" kata informan yang lain. "Saya bahkan sering membuka internet mengenai sistem baru yang dihadapi KPU terhadap Pilkada seperti aplikasi klik serentak atau gakkumdu sebagai wadah pelaporannya" lanjut yang lain. "Saya mengamati di berita-berita terkadang masih banyak bentuk-bentuk pelanggaran dalam Pilkada baik yang bersifat pidana maupun kode etik dari para petugas itu sendiri" kata yang lain. "Saya memilih bupati selalu dari kualitas yang ada 
pada dirinya, yang tujuannya untuk kemakmuran rakyat bukan banyaknya uang yang dapat mempengaruhi suara rakyat". Hasil wawancara tersebut menunjukkan adanya sikap dari masyarakat tingkat menengah ke atas, meskipun dari hasil wawancara tersebut masih banyak yang kurang detail atau jeli terhadap hakikat Pilkada sebenarnya, khususnya terhadap pelanggaran-pelanggaran yang seringkali terjadi di lingkungan masyarakat.

Pada hakikatnya hukum merupakan aktivitas masyarakat atau seseorang dalam mematuhi dan/atau tidak mematuhi hukum yang saat ini berlaku. Dalam pandangan Soerjono Soekanto bahwa perilaku hukum menjadi hal yang utama dalam kesadaran hukum, karena hal tersebut memperlihatkan bagaimana penerapan peraturan di masyarakat, sudahkah berlaku atau tidak di dalamnya. Arti sebenarnya seberapa jauh kesadaran masyarakat terhadap peraturan-peraturan yang di buat dengan melihat pola kehidupan/perilaku mereka terhadap hukum itu sendiri. ${ }^{34}$ Perilaku hukum pemilih atau masyarakat terhadap pemilihan merupakan aktivitas seseorang atau masyarakat yang berhubungan dengan pendataan, proses pelaksanaan seperti kampanye, pemilihan/pencoblosan, serta mengevaluasi terhadap pemilihan yang sudah dilaksanakan untuk memenuhi kebutuhan dan keinginan yang sudah terpola dalam diri sesuai dengan aturan hukum yang berlaku baik hukum tertulis maupun tidak tertulis.

Fakta menjelaskan pada masyarakat yang berkategori menengah ke atas dan bukan pada kategori masyarakat menengah ke bawah dalam konteks ini, sebagaimana contohnya: masyarakat sudah memulai berpartisipasi dengan baik melalui proses coklit (pencocokan dan penelitian) dengan menggunakan protokoler kesehatan yang sudah ditetapkan sebelumnya, masyarakat sudah mulai beberapa memberitakan hal-hal yang kurang sesuai dengan demokrasi seperti melapor petugas yang melanggar kode etik, masyarakat menyadari bahwa pemilihan Pilkada tahun ini sangat penting dengan menggunakan strategi yang berbeda pada tahun sebelumnya sehingga menjalankannya dengan mulai sesuai dengan aturan-aturan yang ada, masyarakat juga menyadari sepenuhnya terhadap aturan/kebijakan yang di buat oleh pemerintah setempat yang mengatur tentang pelaksanaan Pilkada serentak tahun ini di Era Pandemi Covid-19.

Maka dari itu, berdasarkan pemaparan di atas bahwa kesadaran hukum mulai dari pengetahuan seseorang. Bahwa pada dasarnya pengetahuan hukum menjadi sebuah modal utama seseorang untuk memahami sebuah hukum, dan jika saja pengetahuan hukum tersebut sudah dikuasai maka terbentuk menjadi sebuah sikap hukum dan akhirnya juga akan menumbuhkan perilaku/kebiasaan yang menumbuhkan kesadaran hukum itu sendiri. Jadi, tingkat kesadaran masyarakat terhadap pemilihan kepala daerah khususnya pada tahun ini dipengaruhi oleh faktor pendidikan, ekonomi, agama, dan lingkungan sosial budaya.

\section{Membangun Kesadaran Hukum Masyarakat Terhadap Pilkada di Era Pandemi Covid-19}

Berdasarkan evaluasi Pilkada serentak sebelumnya, terdapat beberapa sorotan yang perlu dievaluasi di Pilkada tahun ini, beberapa di antaranya: 1) tidak akuratnya data pemilih tetap (DPT), 2) netralitas dari penyelenggara yang masih terdapat masalah, 3) masih banyaknya money politik. 3 hal ini yang harus menjadi perhatian penting agar permasalahan di atas tidak terulang kembali, oleh karena itu Bawaslu dan KPU harus mengoptimalkan kerja

\footnotetext{
${ }^{34}$ Soerjono Soekanto, 215.
} 
secara bersama-sama. ${ }^{35}$ Lebih parahnya melihat kondisi yang telah disampaikan sebelumnya yakni hadirnya pandemi Covid-19 menjadikan pelaksanaan pemilihan memiliki tantangan yang sangat besar dan belum pernah sama sekali diperkirakan akan terjadi keadaan yang menghebohkan dunia seperti ini. ${ }^{36}$ Semua itu akan berdampak bagi pemilih, partai politik, penyelenggara, hingga pemerintah dikarenakan akan membutuhkan modal dan usaha yang lebih besar daripada Pilkada yang sebelumnya, sehingga pemerintah beserta para penyelenggara harus mengonsepsikan strategi yang baru agar Pilkada tetap terlaksana, namun hasilnya pun juga tetap maksimal.

Masih rendahnya kesadaran hukum di tengah masyarakat juga menjadi salah satu penyebab terjadinya kegelisahan di atas atau menjadi faktor-faktor yang melatarbelakangi kekurangan Pilkada pada tahun-tahun sebelumnya, khususnya pada daerah lokal di Kabupaten Pemalang semakin mempertegas problematika yang dihadapi oleh masyarakat beserta penyelenggaranya di Era Pandemi Covid-19. Oleh karena itu, diperlukan upaya pembangunan kesadaran hukum di tengah masyarakat agar terwujud kesadaran hukum terhadap Pilkada serentak pada khususnya di Era pandemi Covid-19 ini. Argumentasi empiris yang melandasi upaya membangun kesadaran hukum masyarakat Pemalang terhadap pemilihan, antara lain: pertama, kesadaran hukum masyarakat terhadap pemilihan masih terbilang rendah, khususnya untuk masyarakat dalam kategori menengah ke bawah; kedua, di Era pandemi Covid-19 menuntut kesadaran masyarakat secara maksimal terkait pemilihan yang khususnya penyelenggaraan Pilkada yang akan dilaksanakan di tahun ini, sehingga masyarakat bisa mengantisipasi dan terhindar dari berbagai pengaruh-pengaruh yang dapat mengurangi kualitas demokrasi atau hasil daripada pemilihan yang tidak sesuai dengan tujuannya.

Sedangkan argumentasi secara teoritis yang melandasi upaya dalam pembangunan kesadaran hukum masyarakat di Era pandemi Covid-19 adalah hukum dalam melaksanakan fungsi serta tujuannya di masyarakat, harus didukung dengan penerapannya yang efektif dan efisien, baik dalam pengendalian sosial terhadap masyarakat maupun untuk mengubah perilaku/kebiasaan yang diamanatkan oleh hukum itu sendiri, juga termasuk pola budaya yang ikut serta di dalamnya. Fungsi hukum ialah untuk menjadikan perubahan terhadap masyarakat (law as a tool of engineering), di artikan bahwa hukum menjadi alat agen of change dalam memelopori perubahan masyarakat yang disesuaikan dengan tujuan hukum sebelumnya. Pelopor dalam hal ini, agar masyarakat sadar terhadap kontestasi politik atau pemilihan dalam menjalankan kerangka demokrasi, pada khususnya pemilihan kepala daerah adalah penyelenggara kontestasi itu sendiri yakni KPU atau KPUD, Bawaslu sebagai lembaga pengawasannya, pemerintah, serta partai politik yang menjadi kontribusi nyata dalam pemilihan kepala daerah tersebut.

Dalam pandangan pakar yakni Satjipto Rahardjo menjelaskan bahwa hukum menjadi sarana yang penting dalam menjalankan social engineering, merupakan hukum yang digunakan secara sadar dengan tujuan mencapai ketertiban dan keadaan masyarakat yang di

\footnotetext{
${ }^{35}$ Dabora Sanur, "Persiapan Pilkada Serentak 2020", Singkat, Vol. XI, No. 24, Desember 2019, hlm. 25-26.

${ }^{36}$ Moch. Dani Pratama Huzaini, https://www.hukumonline.com/berita/baca/lt5ef3fe79c7f0b/ada-kekhawatiran-dantantangan-penyelenggaraan-Pilkada-serentak-saat-pandemi/, dikunjungi pada tanggal 27 Juli 2020.
} 
cita-citakan sesuai dengan yang diinginkan oleh hukum itu sendiri. ${ }^{37}$ Social engineering merupakan suatu sistem untuk mempengaruhi masyarakat agar terpengaruh sesuai dengan cita-cita hukum sebelumnya yang sebelumnya sudah diatur dan direncanakan. Jika saja hukum dihubungkan dengan latar belakang masyarakat secara nilai-nilai yang dianutnya, maka kita akan berhadapan dengan nilai-nilai apa saja yang harus diwujudkan oleh hukum itu sendiri. Melihat dari pemaparan tersebut, maka menjadi tugas penguasa untuk memperlihatkan dan menggunakan hukum dalam meng-engine masyarakat, termasuk budaya hukum (legal culture), tujuannya agar kebiasaan hidup mereka sesuai dengan yang diharapkan (role of expectation).

Menurut Lawrence Friedman mengemukakan tentang faktor nilai yang menjadi perbedaan antara masyarakat dengan kehidupan hukum, dikarenakan disebabkan oleh kultur masyarakat yang mereka lakukan. Kultur hukum diartikan sebagai nilai dan sikap yang dimiliki oleh masyarakat yang berhubungan dengan hukum beserta lembaga-lembaganya. Tentunya dengan adanya kultur hukum ini menjadi penyebab seseorang patuh atau tidak patuh terhadap peraturan-peraturan yang ada. Lawrence Friedman menjelaskan lagi pada hakikatnya bahwa kultur hukum menjadi "motor penggerak keadilan" yang artinya menjembatani sistem hukum dengan pola perilaku pada masyarakat. ${ }^{38}$

Permasalahan kesadaran hukum sendiri sebenarnya ditimbulkan karena ada sebuah nilai-nilai baru yang terdapat dalam hukum, yang kemudian menjadi logis bahwa meluasnya fungsi hukum tidak sekedar mengadopsi dari kebiasaan-kebiasaan masyarakat. Adanya sebuah ketidakcocokan antara norma di dalam hukum dengan realitas di masyarakat, faktor yang menyebabkannya karena hukum tidak hanya sekedar mengadopsi apa yang di lakukan oleh masyarakat atau perilaku yang sering dilakukannya, akan tetapi hukum juga menginginkan membentuk norma-norma yang baru. Agar hukum yang dapat memberikan arah sesuai dengan yang di cita-citakan dapat terwujud dengan baik.

Maka dari itu, berdasarkan hal di atas menjadi perhatian yang sangat penting terutama pada khususnya melalui via pendidikan agar dapat dibangun kesadaran hukum yang lebih baik, dengan cara mengajarkan kepada masyarakat secara luas untuk mengetahui dan memahami tentang kontestasi politik dalam ajang Pilkada serentak yang pada khususnya di era pandemi Covid-19 ini. Pendidikan dalam konteks ini, dapat disalurkan melalui penyuluhan hukum dan kampanye hukum oleh para penyelenggara di wilayahnya masingmasing.

Penyuluhan hukum merupakan proses kegiatan dalam rangka untuk meningkatkan kesadaran hukum yang ada di masyarakat dengan menjelaskan tentang peraturan-peraturan hukum kepada mereka. Seringkali penyuluhan dilakukan secara informal agar dapat diterima oleh masyarakat. Penyuluhan sendiri mempunyai 2 metode; pertama, penyuluhan hukum secara langsung yakni penyuluhan yang dilakukan berhadapan secara langsung dengan masyarakat, sebagaimana contohnya: diskusi, ceramah, dan sebagainya. Kedua, penyuluhan hukum yang dilakukan secara tidak langsung yakni penyuluhan yang dilakukan tidak berhadapan secara langsung dengan masyarakat, sebagaimana contohnya: melalui media (radio, televisi) atau tulisan (majalah, surat kabar), dan lain sebagainya. Penyuluhan yang dilakukan secara langsung dalam bentuk bacaan biasanya sangat membantu masyarakat dalam peningkatan kesadaran hukumnya, bentuk bacaan yang berbentuk gambar biasanya

\footnotetext{
${ }^{37}$ Satjipto Rahardjo, Sisi-Sisi Lain Dari Hukum Indonesia (Jakarta: Penerbit Buku Kompas, 2003), 43.

${ }^{38}$ Friedman, Lawrence M, Hukum Amerika: Suatu Pengantar (Jakarta: PT. Tata Nusa, 2002), 33.
} 
lebih mudah diketahui dan dipahami oleh mereka. Penyuluhan hukum ini dapat menjadi sarana yang sangat penting untuk menyadarkan masyarakat terhadap hak-hak dan kewajibannya sebagai warga Negara dalam memilih dan dipilih dalam pemilu maupun Pilkada serta dapat pula menyadarkannya agar di era pandemi ini dapat memakai prosedur sesuai dengan yang dilakukan/diupayakan oleh pemerintah.

Kampanye untuk meningkatkan kesadaran hukum secara konsisten dapat dilakukan, seperti: ceramah, perlombaan, simulasi, sosialisasi, dan lain-lain. Akan meningkatkan pengetahuan dan pemahaman masyarakat terhadap pemilihan kepala daerah serentak; baik dari proses persiapan, pelaksanaan, hingga menjelang hari pemungutan suaranya, selain itu kampanye juga akan meningkatkan pengetahuan dan pemahaman masyarakat terhadap pencegahan virus Covid-19 dengan menggunakan protokol kesehatan dalam proses pesta demokrasi tersebut. Kampanye juga dapat dilakukan melalui media elektronik maupun nonelektronikal, seperti: radio, televisi, media sosial, Koran, majalah, dan lain-lain.

Berdasarkan pemaparan di atas, bahwa upaya dalam peningkatan kesadaran hukum di masyarakat terhadap pemilihan kepala daerah dalam kontestasi politik ini, dapat dilakukan dengan melalui penyuluhan atau kampanye tentang pentingnya partisipasi publik dalam Pilkada beserta landasan hukum atau peraturan-peraturannya. Tujuan akhir dari upaya tersebut agar dapat menciptakan masyarakat yang cerdas dan sadar terhadap pemilihan pada khususnya pemilihan kepala daerah demi kepentingan wilayahnya masing-masing, masyarakat juga memahami hak dan kewajibannya sebagai pemilih yang aktif, memahami bagaimana tindakan masyarakat terhadap penyelewengan-penyelewengan yang ada, serta dapat memilih pemimpin yang berintegritas. Dari hal-hal tersebut menjadi penting agar kedaulatan rakyat selalu tetap terjaga dengan baik di negeri ini.

\section{Kesimpulan}

Kesadaran hukum masyarakat terhadap partisipasi pemilihan, khususnya Pilkada dilihat dari beberapa aspek, yakni : pengetahuan, pemahaman, sikap dan perilaku hukum. Pada masyarakat yang berkategori menengah ke bawah belum memiliki pengetahuan dan pemahaman yang mendalam terhadap Pilkada (pemilihan kepala daerah) beserta kebijakannya, namun untuk masyarakat berkategori menengah ke atas sudah memiliki pengetahuan dan pemahaman yang lebih terhadap hukum dan kebijakan yang ditempuh oleh penyelenggara Pilkada, sehingga sikap dan perilaku mereka terhadap Pilkada ketika dilakukan coklit (pencocokan dan penelitian), pendataan DPT, dan yang lainnya sudah dapat memperlihatkan kewajiban apa saja yang harus dilakukan sesuai dengan aturan-aturan yang ada sebagaimana taat dalam pendataan, mulai mengevaluasi para calon-calonnya, aktif bertanya terkait prosedur di saat pandemi ini, dan menggunakan protokol kesehatan ketika dilakukan pendataan. Bahkan masyarakat sudah mulai yang melakukan pelaporan terhadap petugas yang menyepelekan dalam kinerjanya. Kesadaran hukum masyarakat di pengaruhi oleh faktor pendidikan, ekonomi, agama, dan lingkungan sosial budayanya. Upaya yang dilakukan untuk membangun dan meningkatkan kesadaran hukum mereka dilakukan dengan cara : penyuluhan dan kampanye tentang pentingnya Pilkada serentak di era pandemi Covid-19 ini beserta kebijakan-kebijakan barunya, tujuannya agar terciptanya masyarakat yang mempunyai kecerdasan dan kesadaran terhadap hak dan kewajibannya sebagai warga Negara Indonesia dalam berpartisipasi terhadap pesta demokrasi. 


\section{Daftar Pustaka}

\section{Buku}

Al-Nabawi, 2006, Khadijah al-Nabawi, mausu'ah Huquq al-Insan fi al-Islam, Mesir : Dar AlsalaM

Anwar, Syamsul, 2007, Studi Hukum Islam Kontemporer, Jakarta: RM Books

As'ad, Abdul Muhaimin, 1993, Risalah nikah penuntun perkawinan, Surabaya: Bintang Terang99

Adhim, Mohammad fauzil, 2012, Mencapai pernikahan barokah, yogyakarta: Mitrapustaka

Al-Muslim, Al-Bukhori,2011, Ensiklopedia Hadist Shahih al-bukhori 1, terjemah Masyhar dan Muhammad Suhadi, Jakarta:Almahira Cet-1

Basyir, Ahmad Azhar, 1983, Hukum Adat Bagi Umat Islam,Yogyakarta: Nur Cahaya.

Basri, Hasan, 1996, Merawat Cinta Kasih, Yogyakarta : Pustaka Pelajar

Bastaman, H.D., 1996, Meraih Hidup bermakna kisah pribadi dengan pengalaman tragis, Jakarta:Paramadina

Bakry, Sidi Nazar ,1993, kunci keutuhan Rumah Tangga, Jakarta:pedoman jaya

Kuswara,1991, teori-teori keperibadian, Bandung: Eresco,cet.ke-2

Dr. H. Hasbiyallah,M.Ag, 2015, keluarga sakinah, Bandung: PT Remaja Rosdakarya

Djamil, M.Nasir, 2013, Anak Bukan untuk dihukum, Jakarta : Sinar Grafika

Departemen Pendidikan dan Kebudayaan, 1990, Kamus Besar Bahasa Indonesia, Jakarta: Balai Pustaka

Daradjat, Zakiah, 2012, , Ilmu Pendidikan Islam, jakarta: bumi aksara

Departemen agama, 1993, kamus besar bahasa Indonesia , Jakarta:balai pustaka

Faridh, Miftah, 1983, Keluarga Bahagia, Bandung : Pustaka

H. Hendri, 2000, pengantar studi sosiologi keluarga, Bandung: CV Pustaka Setia

Hasbullah, 2011, Dasar-dasar Ilmu Pendidikan, Jakarta: Raja Grafindo, 2011

Hadikusumo Hilman,1995, Hukum Perkawinan Adat, Bandung:PT Cipta Bakti

IAIN Jember,2017, Pedoman Penulisan Karya Ilmiah, Jember: IAIN Jember Press

IAIN Jember,2018, Pedoman Penulisan Karya Ilmiah, Jember: IAIN Jember Press

J'Moleong, Lexy, 2011, Metode Penelitian Kualitatif ${ }_{\llcorner}$Bandung: PT Remaja Rosdakarya

Masyhuri, Sayyid Abi Bakr Al, 1992, Al-Ianah At-Talibin, Semarang: Toha Putra

Muchtar, Kamal, 1974, asas-asas hukum Islam tentang perkawinan, Jakarta:bulan bintang

Mustakim, Abdul, 2006, kedudukan dan hak-hak anak dalam perspektif Al-Qur'an, , Artikel, jurnal Musawa, Vol.4 No.2

Nasution, Bahder, 2016, Metode Penelitian Ilmu Hukum, Bandung : CV Mandar Maju

Nasution, Khoiruddin,2011, Hukum Keluarga (Perdata) Islam Indonesia, Yogyakarta : ACA de MIA + Tazzafa

Purwanto, M. Ngalim, 2009, Imu Pendidikan Teoritis dan Praktis, Bandung: PT Remaja

Roqib, Moh, 2011, Ilmu pendidikan Islam, Yogyakarta: LKS Group

Sugiyono,2011, Metode Penelitian Kuantitatif Kualitatif dan RED, Bandung: Alfabeta

Suhendi, Hendi, 2001, , Pengantar Studi Sosial Keluarga, Bandung : Pustaka Setia

Sutopo, 2002, Metodelogi Penelitian kualitatif, Surakarta: sebelas maret university press

Soelaeman, M.Munandar,1989, Ilmu Sosial Dasar, Teori dan Konsep Ilmu Sosial,Bandung: PT ERESIO Bandung

Thalib, Sayuti,1986, Hukum kekeluargaan Indonesia, cet, ke-5, Jakarta: Universitas Indonesia

Uhbiyati, Nur, 2013, Dasar-dasar Ilmu Pendidikan Islam, semarang: pustaka Riski Putra 


\section{Perundang-undangan}

Undang-Undang Republik Indonesia Nomor 1 Tahun 1974 Tentang Perkawinan,

Undang-Undang Republik Indonesia Nomor 23 Tahun 2002 Tentang Perlindungan Anak 